\author{
MINERALOGIA POLONICA \\ 10.2478/v10002-007-0008-7 \\ PL ISSN 0032-6267 \\ Vol. 37, No 1, 2006
}

\title{
ZYGMUNT HOLCER \\ 10.11.1925-17.07.2004
}

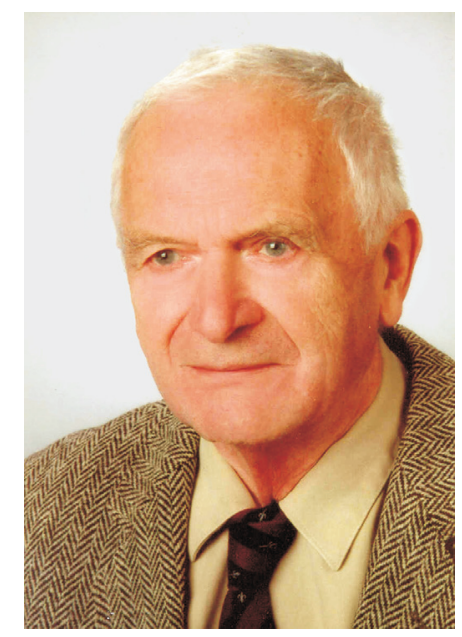

Born in Cracow, Zygmunt Holcer completed a primary school and attended initial classes of the B. Nowodworski lycee in Cracow before the war. Arrested with his father by the Nazis in February 1943, sent with the death sentence to the Auschwitz concentration camp. Incarcerated till September 1944, underwent ",medical” experiments there. Next, an inmate of the Buchenwald, Buchenwald-Ohrdruf and Flossenberg concentration camps. Released on 8 May, 1945, and returned to Cracow. He passed his maturity exam in July 1946 and was admitted to the Jagiellonian University, Faculty of Mathematics and Natural Sciences, where he majored in Biology. In 1948-1951 he worked at the Tuberculosis Institute in Cracow, then in the Antituberculosis Sanatorium in Rabka till 1954 and, finally, till his retirement in 1981 in the Cracovian Plant of Serums and Vaccines.

He was active in the Association of Disabled Soldiers and the Association of Combatants and Former Political Prisoners till his last months. For his social involvement he was aworded many times, among others with the Cavalier Cross (1984) and the Officer Cross (1990) of Polonia Restituta Order, the Auschwitz Medal (1987), and the Medal of the Maximillian Kolbe Werk Association (1995) in the 50th anniversary of the war end and liberation from the concentration camps.

Zygmunt Holcer, a biologist by his studies and occupation, had many other passions. He was a gifted photographer, a member of the Polish Photographic Society and one of the founders of the Cracow Photographic Society; he showed his camera meetings with the nature in seventeen artistic exhibitions. Zygmunt Holcer was also interested in medieval military architecture of the Cracow region, working in the "Architectura Militaris" Section of the Commission of Town-Planning and Architecture of the Polish Academy of Sciences (Cracow Branch), and co-operating with the Ojców National Park. The results were presented at many meetings and also published in professional papers. He was also a book-lover, possessing a rich library of $19^{\text {th }}$ and $20^{\text {th }}$-century specimens.

But his greatest passion was collecting minerals and fossils. He specialized in agates, volcanite rocks and fossil wood, which he exhibited more than 30 times, e.g. at the International Fairs of Minerals, Stones, Fossils and Jewellery, organized by the Ge- 
ological Museum of the Academy of Mining and Metallurgy and at the International Fairs of Minerals "Wawelstone". He was awarded with 25 diplomas for taking the first or the second places for his mineral collections. Some of them were also temporarily exhibited in Cracow museums (Natural of the Polish Academy of Sciences, Archaeological of the Jagiellonian University, Geological of the AGH), in the Gallery of Odds "Este" and elsewhere, also outside Poland (France, Slovakia). He belonged to the Section of Lovers of Minerals and Fossils in the Polish Association of Earth Science Friends, which he was a very active member, awarded with a commemorative medal. He also authored or co-authored 7 papers in professional Polish geological and mineralogical journals.

For many of us - mineralogists, Zygmunt will be remembered not only as a person who could always talk about minerals, but also as our friend and companion of field trips and many evenings spent by campfires where he could discuss everything, from his beloved "stones" to very different topics.

Zygmunt Holcer offered his geological collection to the following institutions in Cracow:

$>$ Geological Museum of the Stanisław Staszic Academy of Mining and Metallurgy in 1993;

$>$ Museum of Natural Sciences of the Jagiellonian University in 2003. Some 2500 agates (currently being described) enriched the Volcanite Section of the Museum;

$>$ Paleobotanical Museum at the Institute of Botany of the Jagiellonian University. The collection composed of some 2500 specimens of fossil wood (currently being described) was partly exhibited in January 2003.

Papers and oral presentations of Zygmunt Holcer in the field of mineralogy:

$>$ Paleontological and paleobotanical specimens in Z. Holcer's collections. Kamienie (bimonthly journal of the Section of Lovers of Minerals and Fossils, Polish Association of Earth Science Friends, Cracow Branch). Kraków, IX-X.1990 (in Polish).

$>$ Mineralization of caverns in the Sudetic volcanites. Pol. Tow. Miner. Prace Spec. 5, 110, 1994. Also oral presentation, a poster and the exhibition at the session commemorating the $25^{\text {th }}$ anniversary of the Mineralogical Society of Poland.

$>$ Mineralogical investigation of silificied wood and the Kwaczała arkose (S Poland). Co-author: M. Pawlikowski. Arch. Miner. L, 1, 69-88, 1994 (in Polish, with English abstract and summary).

$>$ Agates from a melaphyre hill in Rudno (selected geological and mineralogical problems). Oral presentation at a meeting of the Mineralogical Society of Poland, Cracow Branch, combined with an exhibition "Agates from the Cracow region in the collections of Z. Holcer and A. Pieczka", February 1996 (in Polish).

$>$ Various mineral incrustations of wood. Oral presentation at the scientific meeting organized jointly by the Commission of Mineralogical Sciences, Cracow Branch of the Polish Academy of Sciences and the Chrzanów Museum, September 1996 (in Polish). 
Agates of Cracow region compared with other occurrences in Poland. Co-author: A. Pieczka. Pol. Tow. Miner. Prace Spec.17, 60-62, 2000.

$>$ Application of Upper Jurassic biohermal limestone as an ornamental stone in the $17^{\text {th }}$-century eccelesiastical architeture. Co-author: M. Krajewski. Kwart. AGH, Geologia 27, 2-4, 257-266, 2001 (in Polish with English abstract and summary).

Teresa MAEKOWSKA-HOLCEROWA

Andrzej SKOWROŃSKI 